University of Rhode Island

DigitalCommons@URI

Open Access Master's Theses

1979

\title{
OPPOSING GROWTH POLICIES IN ADJACENT TOWNS: A STUDY OF PLYMOUTH AND WAREHAM, MASSACHUSETTS
}

Deborah A. Shealy

University of Rhode Island

Follow this and additional works at: https://digitalcommons.uri.edu/theses

\section{Recommended Citation}

Shealy, Deborah A., "OPPOSING GROWTH POLICIES IN ADJACENT TOWNS: A STUDY OF PLYMOUTH AND WAREHAM, MASSACHUSETTS" (1979). Open Access Master's Theses. Paper 392.

https://digitalcommons.uri.edu/theses/392

This Thesis is brought to you for free and open access by DigitalCommons@URI. It has been accepted for inclusion in Open Access Master's Theses by an authorized administrator of DigitalCommons@URI. For more information, please contact digitalcommons-group@uri.edu. 
OPPOSING GROWTH POLICIES IN ADJAGENT TOWNS:

\author{
A STUDY OF \\ PLYMOUTH AND WAREHAM, MASSACHUSETTS
}

BY

DEBORAH A. SHEALY

\begin{abstract}
A RESEARGH PROJECT SUBMITTED IN PARRIAL FULFTIIMENT OF THE REQUIREMENTS FOR THE DEGREE OF MASTER OF COMMUNITY PLANNING
\end{abstract}

UNIVERSITY OF RHODE ISLAND

MAY 1979 
MASTER OF COMMUNITY PLANNING

RESEARCH PROJECT

$\mathrm{OF}$

DEBORAH A. SHEALY

\section{Approved:}

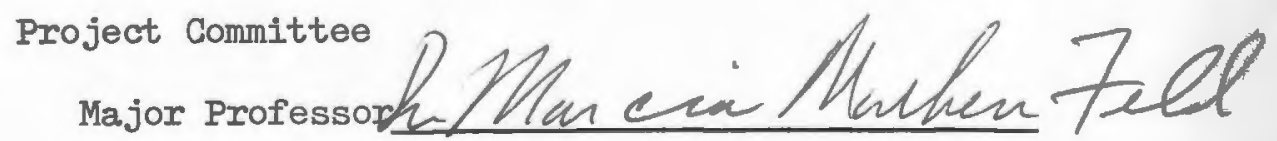

Director of the Graduate Curriculum of Community Planning

UNIVERSITY OF RHODE ISLAND

MAY 1979 


\section{TABLE OF CONTENTS}

I. Introduction 1

II. Growth Policy - A Conceptual Framework 5

III. Community Profiles 9

$\begin{array}{lr}\text { Plymouth } & 10\end{array}$

$\begin{array}{ll}\text { Wareham } & 16\end{array}$

IV. Local Growth Policies 23

v. Implementation and Recommendations 35

VI. Conclusion 40

$\begin{array}{ll}\text { Maps } & 42\end{array}$

$\begin{array}{ll}\text { Appendix } & 45\end{array}$

$\begin{array}{ll}\text { Footnotes } & 48\end{array}$

$\begin{array}{ll}\text { Bibliography } & 49\end{array}$ 


\section{LIST OF TABIES AND GRAPHS}

Graph of Population Increases

Plymouth, 1930-1975

Age of Housing Units Plymouth, 1970

Table of Retail Trade

Plymouth, 1974

Table of Employment and Payrolls Plymouth, 1974

Graph of Population Increases

Wareham, 1930-1975

Age of Housing Units

Wareham, 1970

Table of Retail Trade

Wareham, 1974

Table of Employment and Payrolls Wareham, 1974

Map A 
I. INTRODUCTION 
Growth management would appear to be the key phrase in the field of planning for the coming decade. It is not a new idea, but one which has ignited both the interest and criticism of practisioners and theorists alike. It may well be a concept that's time has come. As the hidden costs of growth become more apparent, a new attitude is gradually emerging; one which stresses the importance of preserving the natural and cultural characteristics which make up a "humanly satisfying living environment." 1

The essential goal of growth management is closely related to the basic goal of city planning itself. Growth management attempts to organize, control, and coordinate the process of urban development so as to protect what we value in environmental, cultural, and aesthetic characteristics of the land while meeting the essential needs of the changing U.S. population for new housing, roads, energy, recreational, commercial and industrial facilities, and human services. ${ }^{2}$ It is a concept which incorporates when, where, and in what manner growth should be accommodated. As a policy, it must address the physical, social and cultural, and political aspects of the "character" of a community, and which must generate a plan to preserve or improve this character. The physical aspects of a community's character are easily the most manifest; narrow roads, panoramic views, historic buildings, plentiful open space, 
and traditional town centers combine in a distinctive way in each community and often account for its residents' sense of identity and pride. The social and cultural aspects, while less obvious, are equally important. Social and ethnic diversity, close-knit neighborhoods, traditional New England settlement patterns, and shared values form the basis for the town's sense of heritage. Finally, the political aspect of the character of a community consists largely of a strong tradition of home rule, and a reliance upon the town meeting form of government. This type of political forum indicates dependence on part-time local officials and a high level of citizen participation; factors which contribute to the residents' sense of concerm about the town and its course of future development and growth. 3

Applied on a local level, growth management or growth/no-growth policies are perceived as merely affecting the geographic distribution of people and economic activity within some larger society, such as the region or state. The determination of this distribution, however, may affect more than the physical land use configuration of the region. It may also alter established delivery systems for human services by shifting urban development patterns, thereby creating new centers and disrupting old neighborhoods.

In the course of developing a growth management policy for a state, it is possible to have instances where two contiguous townships may have conflicting goals regarding growth; goals which may eventually result in problems in the development and use of the common border. In the state of Massachusetts, such a situation exists between the towns of Plymouth and Wareham. Plymouth has experienced tremendous growth in the last de- 
cade and has adopted a policy designed to limit future growth. Wareham, on the other hand, has endorsed an active growth-seeking policy. There are potential problems implied in the subsequent implementation of these growth policies. Conflicting land uses, disruption of service delivery, and the extension of the infrastructure of one of the towns might create serious repercussions in the adjacent township.

An analysis of the growth policies of these two towns (Plymouth and Wareham), reveals the potential problems to be faced by these communities, and others in a similar situation, as they develop along their respective guidelines. The conceptual framework of growth policies in general, will be discussed, followed by a comparison of the past development and current demographic, economic, and political characteristics of each town. This should provide some insight into how these towns attained their current attitude/policy toward future development. The specific growth policies of Plymouth and Wareham will then be analyzed, identifying potential areas of conflict between the two communities. Finally, recommendations will be submitted as to how each of these towns might best implement the policy and programs developed to achieve their respective goals without harmfully disrupting the development of neighboring towns. 
II. GROWTH POLICY - A CONCEPTUAL FRAMEWORK 
Conceptually, the development of a growth policy follows the same framework as the formulation of any other policy. It involves the process of identifying goals, gathering information, developing alternative choices of programs or policies, determining the "best" alternative to achieve the stated goals, and finally, implementing the policy. This basic framework is used by all levels of government for all hierarchies of policy making. For this discussion, the process used by individual towns in determining a growth management policy is of particular interest.

In the earliest stages of developing a growth policy, it is important that the residents come to a concensus on the goals for the town. This initial step requires that a town determine which aspects of the community are good, which are bad, which should be retained, which should be eliminated or corrected. In establishing goals, town residents should consider factors such as the character, environmental assets, economic base, and recent trends in development, to help them decide how they would like the town to develop over the next ten or twenty years. Once a set of goals has been agreed to, the second phase begins.

It is important that the town find out where it is located on its development continuum. In order to do this, the town researches infor- 
mation relating to its past development; identifying trends in population growth, residential and commercial construction, and municipal service expansion, among others. The town should also take an inventory of any unused land, developable areas, under-utilized areas, crowded areas, and open spaces to be preserved. This will provide the town with an indication of those areas which can, and cannot, accommodate any future growth or development, as well as sections of the town which will most likely experience growth in the near future. This information will give the town some idea of its stage of development. In the third phase, the town combines the information it has collected with the set of goals to formulate possible alternative growth policies which the town might adopt.

When developing a growth policy for a town, the alternatives are readily apparent. Towns can either: ignore the growth issue entirely by not adopting any policy; adopt a policy which encourages growth; endorse a policy which limits future growth; or, adopt a policy which prohibits any further growth. For most communities, it is really a choice between the policies of encouraging or limiting growth.

Now the town must evaluate each of the alternative policies in terms of impact analysis and the relationship of the policy to the goals. An impact analysis involves evaluating what the possible effects of each policy will be on the town. For example, if a town were almost completely developed, a policy encouraging growth might result in overcrowding, housing shortages, poor municipal services, and a loss of any remaining environmental assets (i.e.: air and water quality). If the town had set these results as desired goals, then the policy would be 
the best one for the town, and hence adopted. It is more likely, however, that a policy of growth limitation would be selected. It is essential that the policy selected among the alternatives as the best, meet the goals of the town and be consistent with their current state of development and capacity for growth.

When the goals have been set, information gathered, and the growth policy selected, the town must then develop a plan/program for implementing the policy. Primarily, this involves adopting a set of specific measures or strategies which will, when implemented, achieve the goals designated by the town. These measures can include: tax incentives for industry; public land aquisition; large lot zoning; moratoriums or interim zoning; limited expansion of municipal services or infrastructure (sewers, utilities, etc.); temporal land use controls; center revitalization; building restoration; and, environmental controls. These strategies and land use tools can help a town get control of, and effectively manage, its growth.

The following sections will briefly compare the demographic, economic, and political characteristics of the town of Plymouth and Wareham, and will take a close look at their respective growth policies. 
III. COMMUNITY PROFIIES 


\section{PLYMOUTH}

Plymouth, Massachusetts is a small city located in the southeastern section of the state. It is adjacent to the towns of Bourne, Carver, Kingston, and Wareham, and the Atlantic Ocean to the east. Plymouth also borders on the Boston Standard Metropolitan Statistical Area. For state planning purposes, it is included in the old Colony region, with the city of Brockton designated as the regional center. Because of its location ( 38 miles from Boston, 44 miles from Providence, Rhode Island, and 24 miles from Brockton), Plymouth serves as a secondary center. (See Map A.)

Plymouth is one of the oldest towns in the nation, as well as in the state of Massachusetts. It was established as a town on December 21, 1620. The town is rich in historical significance and has attempted to uphold the legacy of its heritage through the preservation and restoration of historic structures, enforcement of design control standards, and the implementation of development goals which will retain the town's village-like character.

\section{population}

The preservation of an historic village atmosphere has not been easy over the last decade. The population of the town has increased steadily since 1930, with the greatest growth occuring during the ten 
years from 1965 to 1975 . In this decade alone, the number of residents grew from 15,424 to 26,907 ; an increase of $74 \% .^{1}$

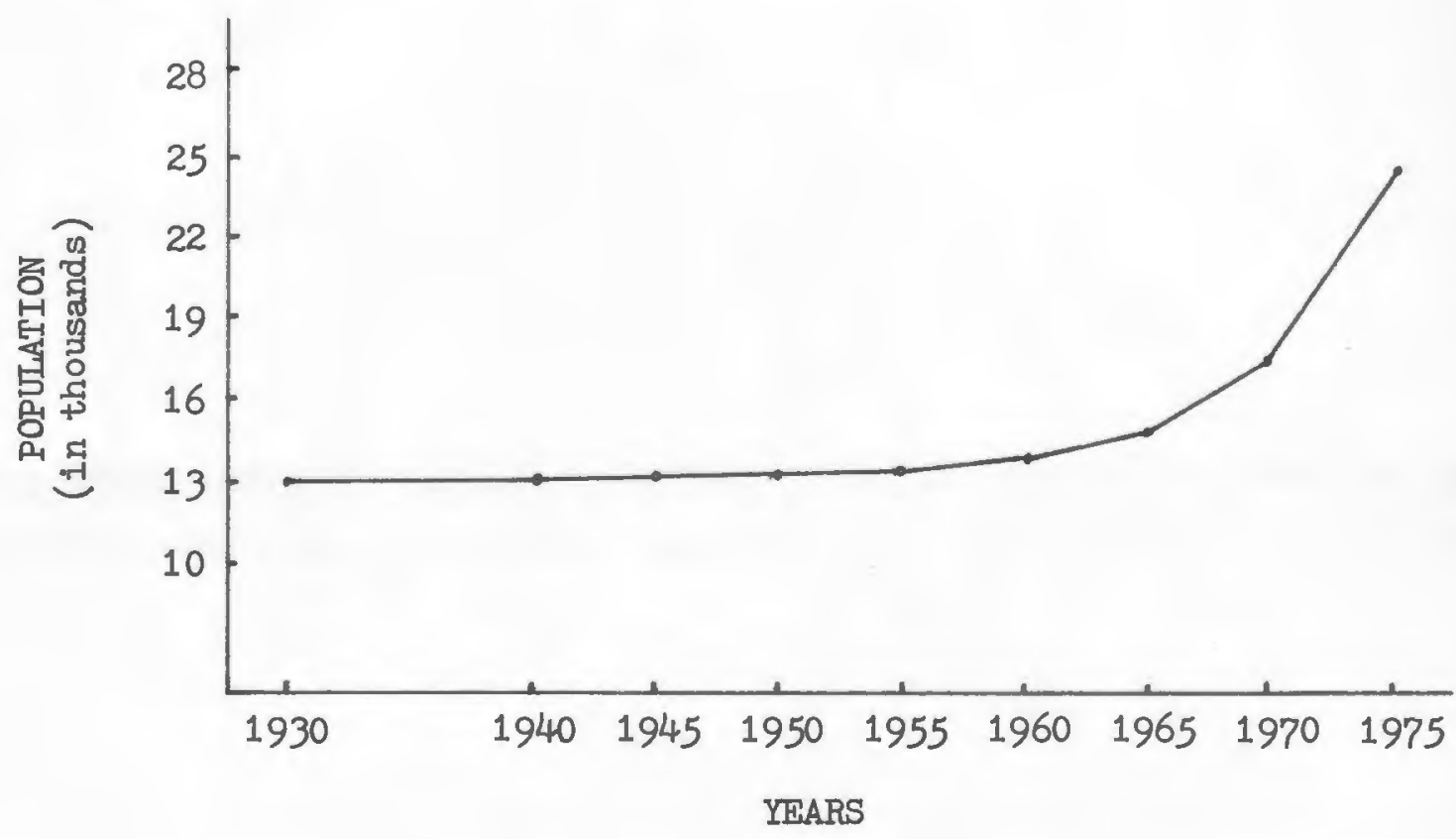

POPULATION OF PLYMOUTH

$\begin{array}{lll}1930-13,042 & 1950-13,608 & 1965-15,424 \\ 1940-13,100 & 1955-13,892 & 1970-18,606 \\ 1945-13,536 & 1960-14,445 & 1975-26,907\end{array}$

(Source: Massachusetts Profile of Plymouth)

This rather sudden increase in population is due, primarily, to the completion of Route 3 (Southeast Expressway). Development spread down from the greater Boston area, creating a new commuter link to the city. There are 97.57 square miles included within the town boundaries. During the same period (1965 to 1975), the average density per square mile rose from 158 persons to 276; an increase of approximately $75 \%$. 
$\underline{\text { housing }}$

According to the 1970 U.S. Census, of the 8631 housing units in Plymouth, 6488 were occupied and 169 or $2 \%$ were vacant. Of these occupied units, $61.8 \%$ were owner-occupied and $38.2 \%$ were rented. The majority of the housing structures in Plymouth, $60.5 \%$ as of 1970 , were of the single-family type. Duplexes constituted $16.1 \%$ and multi-family structures (three or more units) made up $21.4 \%$. Roughly $2 \%$ of the housing structures in 1970 were mobile homes or trailers. 2

Due largely to Plymouth's early development as a town, the majority of housing units are forty or more years old. The table below presents a breakdown of housing units based on age.

\section{AGE OF HOUSING UNTTS - PLYMOUTH}

\begin{tabular}{lcc} 
Year Built & No. of Units & Percent \\
\hline 1965 - March 1970 & 1161 & $17.0 \%$ \\
1960 - 1964 & 451 & 6.6 \\
1950 - 1959 & 828 & 12.1 \\
1940 - 1949 & 340 & 5.0 \\
1939 or earlier & 4060 & 59.3 \\
(Source: U.S. Census, 1970)
\end{tabular}

Many of the older structures are to be renovated and used for commercial or office space in addition to housing. New dwelling units built within the last five years have predominently been single-family structures, with a much smaller number of multi-family units or apartment complexes constructed. The town hopes to fulfill future housing needs by combining single-family and multi-family units in each new development. 
economic base

In its early development, agriculture, navigation, and commerce comfortably supported the inhabitants of Plymouth. By 1830, the town's population had increased to 5000, and over 100 ships were engaged in coast-wide trade and fishing. On land, mining and manufacturing were becoming important industries. Plymouth supported five iron mills, two cotton mills, and three ropeworks. A little later in its development, the town was also a major producer of candles.

Today, Plymouth is primarily a commercial center and a summer resoxt. In 1974, the largest source of employment in the town was the wholesale and retail trade industry. It employed $39.7 \%$ of the total working population; supplying $34.8 \%$ of the total annual payroll for that year. The second largest employer was the service industry, and manufacturing was third.

The wholesale and retail trade industry (in 1974) consisted of 23 wholesale and 166 retail firms, employing an average of 342 and 1709 persons, respectively. The combined annual payroll for the industry was $\$ 12,496,041,3$ The retail trade aspect of this industry is itemized in the following table.

\section{PLYMOUTH RETAIL TRADE}

\begin{tabular}{lccc} 
Classification of Bus. & Estab. & $\begin{array}{c}\text { Annual } \\
\text { Sales }\end{array}$ & $\begin{array}{r}\% \text { of } \\
\text { Total }\end{array}$ \\
\hline Bldg. Material, Hardware, Farm Equip. & 12 & $\$ 2,840,000$ & $4.8 \%$ \\
General Merchandise Group & 4 & $*$ & - \\
Food Stores & 31 & $17,455,000$ & 29.5 \\
Automotive Dealers & 15 & $14,285,000$ & 24.1 \\
Gasoline Service Stations & 21 & $3,216,000$ & 5.4
\end{tabular}




\begin{tabular}{|c|c|c|c|}
\hline Classification of Bus. & Estab. & $\begin{array}{r}\text { Annual } \\
\text { Sales } \\
\end{array}$ & $\begin{array}{l}\% \text { of } \\
\text { Total }\end{array}$ \\
\hline Apparel, Accessories Store & 7 & $\$ 3,411,000$ & $5.8 \%$ \\
\hline Furmiture, Home Furnishings, & Equip.18 & $2,148,000$ & 3.6 \\
\hline Eating and Drinking Places & 46 & $5,288,000$ & 8.9 \\
\hline Drug and Proprietary Stores & 8 & * & - \\
\hline Misc. Retail & 52 & $7,362,000$ & 12.4 \\
\hline
\end{tabular}

The large numbers of eating and drinking places, miscellaneous retail establishments, and gasoline service stations are indicative of Plymouth's role as a seasonal resort.

The service industry, second most important activity in Plymouth's economic base, employed $29 \%$ of the total working population among its 147 firms; producing an annual payroll (in 1974) of $\$ 7,921,612$. The third major industry in Plymouth is manufacturing. In 1974, 27 manufacturing firms reported an average of 600 employees, or $11.6 \%$ of the total work force, and an annual payroll of $\$ 4,398,690$. The largest employers in this industry include: Boston Insulated Wire Cable Co., cable connectors; Memorial Press, Inc., printing; Pixley-Richards, Inc., plastic components; and Revere Copper and Brass, Inc., photo engraving plates of zinc, copper, and magnesium. ${ }^{4}$ The following table illustrates the role each industry plays in the economic base of the town.

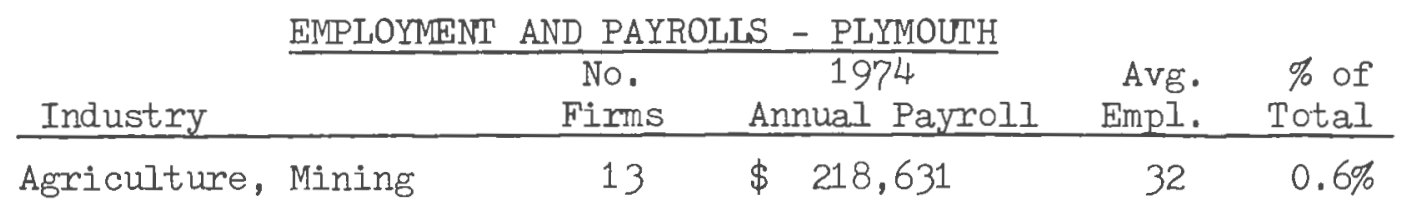




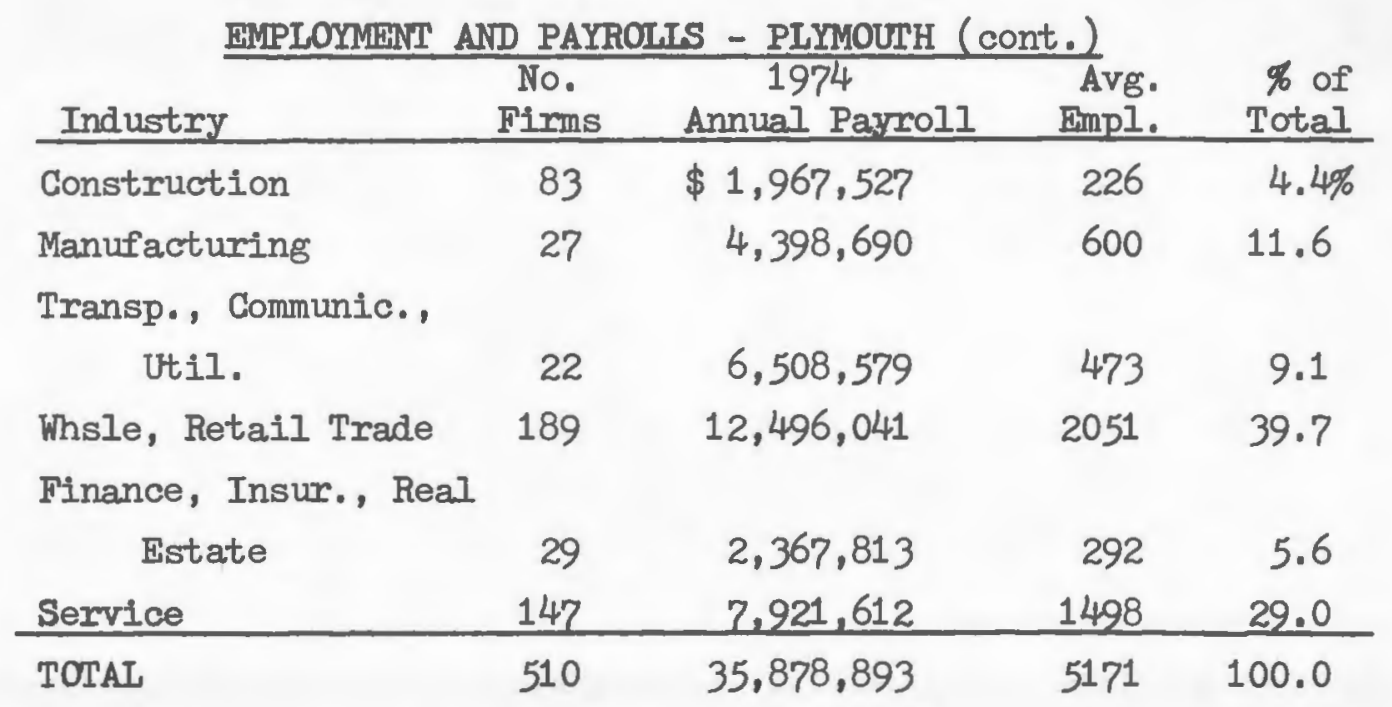

(Source: Massachusetts Profile of Plymouth)

political structure

The town of Plymouth is governed by a Board of Selectmen, and uses a limited town meeting format of conducting local government operations. There is an established planning office with two full-time planners employed. The town is currently developing a master plan with the assistance of a consulting firm. A Planning Board determines zoning and subdivision decisions. A Design Review Board is currently being established. There are numerous community based organizations which provide citizen input at regular town meetings and at special sessions. 
WAREHAM

Wareham, Massachusetts is a moderate size town with a land area of 36.68 square miles. It is bordered by the communities of Marion, Rochester, Middleborough, Carver, and Plymouth, and on the south by Buzzards Bay. The town is included in the Southeastern Regional Planning and Economic Development District for state planning purposes. The cities of Fall River and New Bedford are the dominant service centers of the region. Wareham lies just outside of the New Bedford Standard Metropolitan Statistical Area. (See Map A.)

Wareham was originally part of Rochester and the Agawam Plantations; both off-shoots from the Plymouth settlement. The area was settled as early as 1678, and was incorporated as a town on July 10, 1739. The current settlement pattern is spread fairly evenly over the town with the principal concentrations along the shore. A tidal shoreline of 57.3 miles is under Wareham's jurlsdiction.

\section{population}

The population of the town has slowly increased (at an average rate of $10 \%$ a year) since 1930 , with a sudden increase of $50 \%$ in the decade from 1965 to 1975. Although Wareham's overall size is smaller than Plymouth, it shares this trend of recently escalated growth. In fact, a large part of this population increase is a spillover from the 
greater Plymouth area.

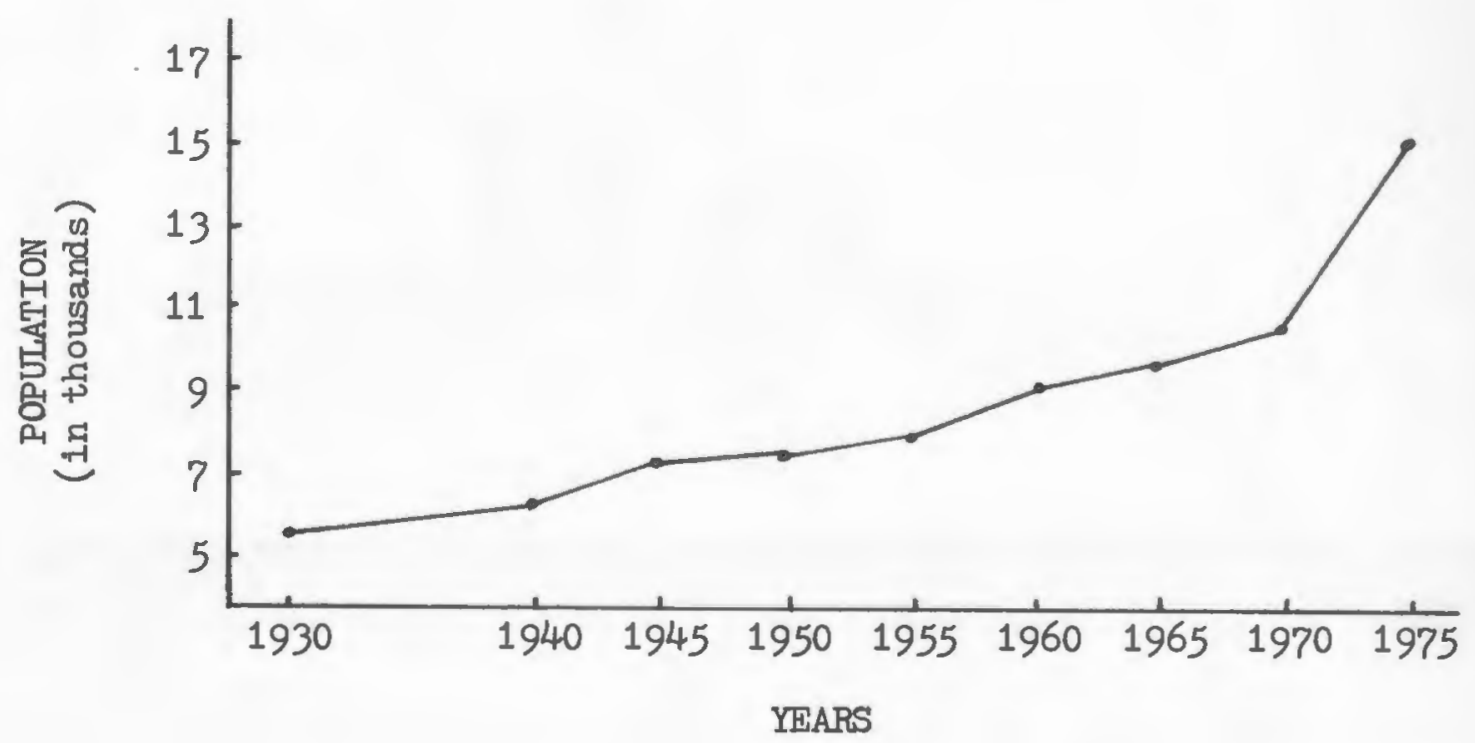

POPULATION OF WAREHAM

$\begin{array}{lll}1930-5686 & 1950-7569 & 1965-10,406 \\ 1940-6364 & 1955-8612 & 1970-11,492 \\ 1945-7439 & 1960-9461 & 1975-15,078\end{array}$

(Source: Massachusetts Profile of Wareham)

The average density of persons per square mile for Wareham also increased sharply between 1965 and 1975. In 1965 there were 284 persons, which rose to 411 in 1975 ; a $45 \%$ increase. 5

$\underline{\text { housing }}$

According to the U.S. Census of 1970, of the 6566 housing units in Wareham, 3719 were occupied and 120 (1.8\%) were vacant and available for occupancy. Of these occupied units, $75 \%$ were owner-occupied and $25 \%$ were rented. An overwhelming majority (82.9\%) of Wareham's housing 
stock are single-family structures. Duplexes make up 5.8\% of the total units. Multi-family structures (three or more units) comprise $7.5 \%$ of the existing housing. Finally, mobile homes and trailers provide the remaining $3.8 \% .^{6}$

Wareham, like its neighbor Plymouth, has a significant number of units built in 1939 or earlier. The following table presents a breakdown of the town's residential units based on age.

\section{AGE OF HOUSING UNITS - WAREHAM}

\begin{tabular}{lcc} 
Year Built & No. of Units & Percent \\
\hline 1965 - March 1970 & 573 & $12.9 \%$ \\
1960 - 1964 & 381 & 8.6 \\
1950 - 1959 & 717 & 16.2 \\
1940 - 1949 & 566 & 12.8 \\
1939 or earlier & 2197 & 49.5
\end{tabular}

(Source: U.S. Census, 1970)

Compared to the age of structures in Plymouth, Wareham experienced either a greater boon in housing construction during the period from 1940 to 1964 , or has retained a greater percentage of units built during those years. The difference in percentages may mean that Plymouth has replaced more of its post-World War II housing stock, while Wareham residents are still using them.

economic base

In its early development, the town of Wareham was primarily engaged in agriculture, shipbuilding, and utilizing local timber as economic ac- 
tivities. In the post-Revolutionary War period, the shipyards became an extension of the whaling industry in New Bedford, and the town began to manufacture salt. With the advent of the Industrial Revolution, Wareham increased its manufacturing sector to include the production of hollow ware and paper, and constructed several cotton mills. The production of nails became a major industry in 1822, with shellfishing and agriculture still prominent activities in the town's economy.

Today, Wareham is primarily a resort town. The present economic base is dominated by three major industries, wholesale and retail trade; service; and manufacturing. The town shares the same economic base structure as Plymouth. Employment in both year-round and seasonal occupations is heaviest in retail trade. Employment in this area ranges from a low of 728 in February to a high of 999 in August (based on 1974 data). A substantial part of this employment is concentrated in eating and drinking establishments which depend on summer trade to survive. In 1974, nine wholesale firms located in Wareham employed an average of 74 persons, and supplied an annual payroll of $\$ 724,782$. Retail firms in the town (129 in 1974) paid an annual payroll of $\$ 4,819,935$ to an average of 895 employees.? The following table shows the distribution of sales from each classification of retail trade.

\section{WAREHAM RETAIL TRADE}

\begin{tabular}{lccc} 
Classification of Bus. & Estab. & $\begin{array}{c}\text { Annual } \\
\text { Sales }\end{array}$ & $\begin{array}{c}\% \text { of } \\
\text { Total }\end{array}$ \\
\hline Bldg. Material, Hardware, Farm Equip. & 10 & $\$ 2,024,000$ & $7.2 \%$ \\
General Merchandise Group & 12 & $4,223,000$ & 15.1 \\
Food Stores & 17 & $5,455,000$ & 19.6 \\
Automotive Dealers & 12 & $3,462,000$ & 12.4
\end{tabular}




\begin{tabular}{|c|c|c|c|}
\hline Glassification of Bus. & Estab. & $\begin{array}{r}\text { Annual } \\
\text { Sales } \\
\end{array}$ & $\begin{array}{l}\% \text { of } \\
\text { Total }\end{array}$ \\
\hline Gasoline Service Stations & 21 & $\$ 3,059,000$ & $10.9 \%$ \\
\hline Apparel, Accessories Store & 14 & $1,154,000$ & 4.1 \\
\hline Furniture, Home Furnishings, Equip. & 11 & $1,591,000$ & 5.7 \\
\hline Eating and Drinking Places & 29 & $2,222,000$ & 8.0 \\
\hline Drug and Proprietary Stores & 4 & 887,000 & 3.2 \\
\hline Misc. Retail & 52 & $3,869,000$ & 13.8 \\
\hline
\end{tabular}

(Source: U.S. Census of Business, 1972)

The number of establishments listed under the various classifications of retail business reveals the seasonal emplasis of the town's economy. Gasoline stations and eating/drinking places are numerous because the seasonal influx of travelers can support them through the spring and summer. In its location at the entrance to the Cape, Wareham does a considerable amount of business from people in transit. The large number of miscellaneous retail businesses refers to the abundance of gift, curio, and souvenir shops and stands along Route 28 (the connector between Routes 25 and $6-$ see Map B).

Manufacturing is also a major economic activity in Wareham. In 1974, 13 firms, employing an average of 256 persons, provided an annual payroll of $\$ 2,246,481 .^{8}$ The principal firm was the Cape Cod Shipbuilding Company. Other firms produced a variety of products including special machinery, canned and preserved fruits, vegetables, and seafood, and fabricated wire products.

Agriculture continues to be a part of the economic framework of the town. Cranberry growing in particular, provides employment in processing 
and seasonal harvesting and maintenance. Production of other fruits and vegetables also contributes to Wareham's economy. The following table (based on the $1974^{\prime}$ Standard Industrial Classification Code), gives a clearer picture of the major industries and their contribution to the economy of the area.

\begin{tabular}{|c|c|c|c|c|}
\hline EMPLOYMENT AN & $\begin{array}{l}\text { ND PAYF } \\
\text { No. } \\
\text { Firms }\end{array}$ & $\begin{array}{c}\text { IS - WAREHAM } \\
1974 \\
\text { Annual Payroll }\end{array}$ & $\begin{array}{l}\text { Avg. } \\
\text { Empl. }\end{array}$ & $\begin{array}{r}\% \text { of } \\
\text { Total }\end{array}$ \\
\hline Agriculture, Mining & 5 & $\$ 137,443$ & 18 & $0.8 \%$ \\
\hline Construction & 41 & 953,550 & 113 & 5.1 \\
\hline Manufacturing & 13 & $2,246,481$ & 256 & 11.7 \\
\hline Transp., Communic, Util. & 13 & 341,541 & 52 & 2.4 \\
\hline Whsle, Retail Trade & 138 & $5,544,717$ & 969 & 44.1 \\
\hline Finance, Insur., Real Est. & 19 & $1,549,121$ & 187 & 8.5 \\
\hline Service & 60 & $4,163,287$ & 603 & 27.4 \\
\hline TOTAL & 289 & $14,936,140$ & 2198 & 100.0 \\
\hline
\end{tabular}

political structure

The town of Wareham is governed by a Board of Selectmen, and uses a town meeting format for conducting local government functions. A Planning Board makes all decisions regarding zoning and subdivisions. There is no full or part-time planner for the town. Any planning work is done by consultants or special committees appointed by the Chairman of the Selectmen. There are few citizen organizations which actively participate in the town meetings.

Historically, the neighboring communities of Plymouth and Wareham 
have developed along similar lines. Although Plymouth has a larger land area, each town has grown at much the same rate in terms of population and economic activity. The major difference between the two towns, regarding their attitudes toward growth, is that Wareham's growth has occured fairly evenly throughout the 36.68 square miles of land area in the community. Plymouth, on the other hand, has a pattern of subdivisions and new housing developments springing up away from established "village" centers, in formerly wooded open space areas. This has detracted from the community's small town character. The following section will examine, in detail, the specific growth policies of each town. 
IV. LOCAL GROWTH POLICIES 
Both towns recognize that the time has come when they must adopt a formal policy regarding expansion and growth. Their individual approaches in dealing with growth, as discussed in their policy statements, are quite different. In relation to the Massachusetts Growth Program, Plymouth has determined that it has nearly reached its capacity for accommodating growth. The town has therefore set a goal of reducing or slowing the current rate of development and in-migration of people. In contrast, Wareham has concluded that it has not yet reached its full growth potential; it has therefore adopted a policy of increasing the rate and extent of development.

Plymouth would like to see a slow rate of growth directed around established village centers, thereby preserving the settlement pattern of the town and decreasing the need for massive expansion of the municipal infrastructure (i.e.: sewer lines, communication lines, utilities, connector roads, etc.). The town wishes to encourage economic development, especially in areas related to the tourist industry and commercial fishing. Plymouth also wishes to attract light industry, and has set aside specific areas for their location on the periphery of the town centers to minimize any increase in traffic congestion, and to allow for buffer zones of open space to help preserve wooded areas and decrease any negative visual or aesthetic impacts. 
Wareham, on the other hand, would like to encourage growth, particularly in residential housing development and employment opportunities. The town is most anxious to develop its marine resources and to increase industrial activity. The town also wants the state to complete construcm tion of Route 25 and to reinstitute commuter rail service to the Boston area. The realization of each of these objectives, they feel, will effectively encourage growth in the Wareham area. Further analysis of each of these policies will identify potential problem areas for both towns.

In Plymouth's case, the growth policiy statement enumerates four key objectives designed to help the town reach its goal of slowed growth. These are: 1) to encourage a balanced growth trend; 2) to broaden the existing economic base; 3) to direct growth into established village centers; and 4) to retain or improve the environmental quality of the town's forests and ponds. First, Plymouth's growth policy emphasizes that any future growth should be balanced. The town would like to coordinate growth in housing and municipal services with the expansion of commerce and industry. A "balanced" approach, in this case, refers to a plan of increasing housing construction in scale with the development of any new economic activity. In the past, housing and industry have developed independently, resulting in sporadic and uncontrolled sprawl. When a firm comes into a town, it not only has an impact on the specific site, but creates new pressures for housing, municipal services, social services, education, etc..

A new firm requires extension of the town's infrastructure to the site. Since most incoming firms locate away from established develop- 
ment, new roads must be constructed to connect the site with existing transportation routes. If the nature of the business requires a great deal of shipping, it may be necessary to construct a new interchange on the nearest freeway. In addition, new power and telephone lines and water pipes/wells must be put in. Aside from the specific site, an incoming firm may also have an impact on the town through pressures for housing and municipal services. A firm not only hires local workers, but also brings in some of their own from other branches or positions within the company. These new residents will need housing, which could feasibly put a strain on the available supply. If the firm has a large labor force, it might even create a housing shortage, possible resulting in new subdivisions. In addition to an increased demand for housing, they will also want to be located near where they work. Sprawl can occur under these conditions. The problem is lessened somewhat when firms locate close to established areas. Even so, an influx of workers and their families will require a variety of services in addition to housing. These include: schools; police and fire protection; medical and dental services; utilities; and, commercial areas. All of these demands can put pressure on the ability of existing facilities to provide services, ultimately resulting in their expansion, thereby opening the area to even more growth.

This problem is just as severe with new residential subdivisions; once completed, the town will have to consider the impacts of such a development in terms of new demand for stores, schools, sewers, and police and fire protection. No business, industry, or large housing development can enter (or leave) a community like Plymouth without affect- 
ing the pattern and/or rate of development in that town.

There are several strategies which the town can use to encourage a balanced growth trend. Foremost among these methods is the use of Planned Unit Developments (P.U.D.). By using a P.U.D. approach, the town would enlist the aid of the incoming firm to determine the impacts it will have on the community and how these impacts might be mitigated. By projecting the number of workers required to operate the new facility, the town can determine whether any new housing stock will be needed and where it could be constructed. The P.U.D. also allows the town's planners to decide if any additional commercial zones will be needed, and where they could be located to best serve the overall development of the town. This approach would allow the town to expand only as far as is necessary to accommodate a particular firm or residential development and its specific support service requirements. This is an attractive strategy for Plymouth, because it would permit some controlled growth without opening up an area for general development.

Secondly, Plymouth would like to broaden its economic base. Primarily, the town would like to foster expansion of its tourist industry in an attempt to "encourage development of historic, cultural, and recreational resources to attract people."1 An expansion of tourism, however, will have serious impacts on the commercial development of the town. This would mean an increase in hotel/motel and campground construction, and auxiliary services such as restaurants, markets, shops, and auto services to cater to the needs of visitors. It would also require an increase in municipal services to deal with the greater influx of people during the summer season. This includes increased fire and police 
protection, parking facilities, and sanitation and litter collection. This policy, in general, promotes a season-oriented economic base expansion. During the remainder of the year, these additional services and facilities would probably be under-utilized or perhaps unnecessary. Although these types of jobs are generally low paying and would only last three to four months, they should provide substantial employment for high school and college students in the summer months. For the majority of Plymouth's labor force, however, a seasonally based economy can mean long layoffs for people employed in tourist related jobs. It is important that the town highlight attractions which can be visited yearround. An example would be colonial Christmas exhibits similar to those conducted in Newport, Phode Island during the winter. Prolonging the tourist season would prevent an annual increase in the number of unemployed persons in the town, which could also be reflected in increased crime and other problems. The town should also be aware that an active tourism promotion policy would attract visitors to the entire upper Cape area. Effects such as increased traffic, and more widespread construction of summer homes will take place in neighboring towns (Carver and Wareham) as well.

In addition to promoting tourism, Plymouth would like to expand its fishing industry. Currently, fishing has a small role in the town's economic activity. The community would like to expand that role by developing the harbor and encouraging support facilities to locate in town. This would mean a tremendous increase in commerce as retail fish stores, marine equipment stores, machine service and parts dealers, trucking, storage facilities, and other maxine related businesses come in. Most 
of these activities would have to be located in close proximity to the water. This in itself poses problems; traffic congestion and parking are already major concerns in this section of town. Also, much of the land along the water is used for residential or recreational purposes. By encouraging the growth of these two industries, Plymouth will not only attract more visitors, but potential residents as well. The support services needed for both industries will provide a large number of jobs always an attraction for new residents. The town must be prepared to direct the residential growth with will accompany the increase in employment opportunities.

Plymouth's economic base can be expanded in several ways. One strategy would be for the town to streamline its permit-issuing system. This would simplify the bureaucratic paperwork required of incoming firms, therefore encouraging companies to come into the area. Another means of attracting industries would be for the town to offer tax incentives. Each of these strategies would reduce the overall control the town has on development, however. Plymouth wants to increase tax revenues, but not increase the amount of developed industrial and commercial land. Here again, a Planned Unit Development would be a good method of control for the town to use. Another possibility might be the use of an overlay zone in the harbor area to permit water-related businesses and activities to be interspersed among existing uses. In this manner, fishing and tourist facilities (parking, sanitation, etc.) could be used jointly; reducing initial and maintenance costs, and promoting a more efficient use of the limited land available in the harbor area.

Another of the growth policy objectives for Plymouth directs that 
future growth, particularly commercial, be encouraged to locate in existing village centers. These centers refer to developed neighborhood commercial areas. There are four such centers within the town: Plymouth Center; North Plymouth; Manomet; and Cedarville. (See Map A.) Promoting growth around these centers will enable the town to preserve its village atmosphere. It will also facilitate any future expansion of municipal services; these centers house precinct headquarters for fire and police, and waste collection (sewer terminals and dump facilities), in addition to necessary commercial facilities (markets, drug stores, laundries, etc.). One possible method of retaining these village centers is to require that all commercial activity in Plymouth be located there. This would prevent (through strict zoning) commercial strip development along roads traversing the town.

Finally, the town has included an objective of preserving the quality and abundance of open space. There are a number of strategies available to meet this objective. Plymouth would like to increase the amount of land zoned as open space. This area would include present agricultural uses plus a buffer zone around the town's many ponds. Most of the agricultural land in Plymouth is used for cranberry growing. Ordinarily, land used for agriculture is considered to be the best for development; primarily because the land is flat, has good drainage, and is clear of dense vegetation. In Plymouth, however, the agricultural land is marshy with unusually poor drainage — perfect conditions for cranberry bogs, but difficult and expensive to develop. In order to create buffer zones around the ponds, the town will have to set up a long-range plan of land acquisition. Many of these areas already contain low den- 
sity resilential zoning classifications, so most of the shore areas are not yet overly developed. The town feels that strictly controlled recreational uses in these area will ensure that they remain valuable and usable resources. If residential development is allowed to continue at the present rate, it is feared that the water quality would diminish quickly due to the proximity of on-site sewage systems. Expanding the town's sewer system would help to maintain the water quality of the ponds, but it would also encourage further development. It is much easier and cheaper for a developer to hook up to existing sewer lines, than it is to put in separate septic systems for each structure... thus making a sewered area more attractive for development.

If Plymouth can adopt some or all of the specific measures submitted here, the town should be able to achieve its four objectives, and thus bring the rate of growth under control. Wareham, on the other hand, has set out three major objectives in its growth policy statement which it hopes will aid the town in achieving its goal of increasing the rate and extent of the town's development.

The first of Wareham's objectives is to broaden the economic base of the town. Wareham is seeking additional employment opportunities for all levels of skill and hopes to do this by attracting light industry. The town wishes to encourage industry, not only as a means of increasing employment opportunities, but also to broaden the town's tax base. By keeping property taxes and prices down, Wareham will become more attractive to developers, thus stimulating future growth. Wareham has employed several strategies to attract industry to the town. In addition to tax incentives and a streamlined permit process, the town 
has recently rezoned several large tracts of land to industrial use. The town has enabled large industries to come in by providing developable areas on established transportation routes (most notably Routes 25 and 28, and Interstate 195).

The second of Wareham's objectives is to improve the current transportation system. The town is particularly anxious to restore commuter and freight rail service to the Boston area. This strategy would provide a powerful catalyst for growth along that transportation corridor. It would hopefully result in a boon similar to the one Plymouth experienced upon completion of Route 3. A rail service would put Wareham in commuting distance of Boston and would make the town a major transportation node for the peripheral systems which service Cape Cod and the coastal cities in southeastern Massachusetts. If the rail line could be designed so that it passes through other growth-seeking areas on its way to Boston, it might prove to be an effective growth stimulating tool for the state. It would also, unfortunately, create a narrow radial pattern of growth emanating from Boston.

A lesser priority is given to the objective of retaining the town's character as a rural seaside community. It would appear to be less important to the town than attracting industry and business which will bring in new residents. The policy statement also mentions that land use controls and zoning should be sufficient to keep development from intruding into too much of the rural lands. As in Plymouth, the primary agricultural activity is cranberry growing, which generally requires lands unsuitable for most types of development. It is ironic that both towns list expanding the economic base as objectives. Plymouth hopes it 
will increase employment opportunities seasonally, and will encourage visitors rather than residents. Wareham hopes the same objective will lower taxes and provide year-round employment to attract new residents. The point of conflict for these two opposing policies would appear to be most prevalent along the common boundary between Plymouth and Wareham. Plymouth has planned to keep most of this area low density residential and open space. The area immediately surrounding the village center of Cedarville will accommodate both medium and high density residential development, particularly along Route 3. This same area of Wareham is currently zoned for agriculture and single-family residences. There may be some conflict in the future if Route 25 is completed. The highway would pass through this section of both towns (see Map B). In that event, it is quite likely that Wareham would make land available along the highway for industrial use. There are a number of fresh water ponds in the area which could be jeopardized depending on the nature of the industries to be located there. This could undoubtedly cause problems of conflicting land uses. If Route 25 is finished, Plymouth and Wareham would do well to communicate with each other and with the State Department of Transportation before committing that area to development. Other problems may arise from the implementation of these policies. If Wareham is successful in its efforts, it may have a spillover effect causing a resurgence of growth throughout the southeastern region of the state. Growth of this kind would generally be accepted only within that region. Most of the communities within that region have adopted growthseeking policies. On either side of Wareham, however, are the 0ld Colony and Cape Cod regions; both are attempting to limit future development. 
Once a new industrial park is developed in Wareham, particularly along the border of Plymouth or Bourne, the resulting impacts will extend outside of the town's geographic jurisdiction. An examination of possible methods of implementing these growth policies should'identify areas of concern not yet addressed by either town. 
V. IMPLEMENTATION AND RECOMMENDATIONS 
Once each town has adopted a growth policy based on a set of goals, it is time to determine what various courses of action may best help the community to achieve them. In Plymouth's case, we are looking for strategies which will slow and stabilize growth. For Wareham, methods of promoting growth are desireable. It is also important to identify any conflicts between the two towns which will be created in the implementation process.

Both towns hold one objective which they hope will achieve different ends. Plymouth and Wareham set expanding the economic base of their towns as a top priority. Implementation of this expansion would have to be done differently in each town, however, to bring about the desired results. Wareham, through tax and land purchasing incentives, should try to bring in labor-intensive industries. This would fulfill their need for employment opportunities of a wide range of skill levels, provide work for currently unemployed residents, and attract new residents. A relatively small number of these kinds of firms would provide a large number of jobs, enabling the town to use less land for industry and possibly preserving more of the rural areas of the town. These industries would, of course, increase the town's tax base thereby lowering property taxes for residents — an attraction for developers as well.

In order for Plymouth to broaden its economic base without dramati- 
cally increasing the rate of population growth, the town should establish incentives designed to bring in capital-intensive industries. Firms of this type have relatively low space and labor requirements. These industries would contribute to the tax base, helping to keep property taxes stable, without opening a surplus of new jobs to attract new residents. Capital-intensive industries do not require extensive support services either. Plymouth is hopeful that a second nuclear power plant (Pilgrim II) will be built in town in the near future. It is exactly the type of capital-intensive industry they should be seeking. This is not to imply that a nuclear power plant is actually desireable in the town. Development of that type carries with it even greater impacts on the community than other, less potentially dangerous industries. It is, however, a good example of a capital-intensive industry; one which requires few laborers, generates high tax revenues for the town, requires few support services, and which needs a relatively small area for its physical plant. Other examples might be professional services (architects, insurance, finance, etc.) and publishing. The fishing and tourist industries currently sought are largely labor-intensive, but are not necessarily a catalyst to growth. In Plymouth, these industries would largely consist of a large number of small establishments, each hiring only a few employees. Positions of this type are generally filled by current residents and would not normally be enough to entice people to move into the area.

The other growth policy objectives differ between the two communities. Plymouth, for example, hopes to preserve large areas of open space. One method of achieving this could be to designate large areas 
as multi-acre or large lot zones. This tends to have exclusionary results, however. An alternative might be cluster zoning. This would allow construction of mixed housing (single-family houses and apartments) with a common open space to be regulated by a residents' association. They could decide, as a group, how to use the common space. Everyone living in the cluster would have access to it and could use it for recreation, firewood collection, or conservation. The cluster development would also require less from the town in terms of infrastructure. Clustered housing needs fewer roads, utility lines, sewer lines, or other expensive municipal services.

Sometimes several goals can be met through the implementation of a single plan. By having their local government work closely with the State planners, Plymouth and Wareham could formulate a coastal zone management plan which would help to achieve preservation and development goals. Plymouth is interested in both enlarging its fishing industry and preserving its beaches, salt marshes, and tidelands. A formal plan of coastal zone management could help the town coordinate both activities so there isn't any conflict. In Wareham, a coastal management plan could help the town restore the shellfish beds in upper Buzzards Bay, and generally manage the use of the town's marine resources.

There is at least one trend which could make implementation of the local growth policies difficult. This is the national energy crisis. It is already causing gasoline prices to rise at unprecedented rates. Deregulation could bring prices up to well over a dollar a gallon within the next year. It can be anticipated that fewer people will be willing to travel long distances to go to work. For Plymouth it could mean 
an unaided reduction in the growth rate as commuters move closer to their jobs. For Wareham, it would most likely mean that Route 25 would not be completed, thus cutting off one of the town's best opportunities for stimulating growth. The gas prices could work to Wareham's advantage, however, if rail service were reintroduced. The trains would be a less expensive means of transporting people and/or goods than conventional gas-powered vehicles. Depending on how soon Wareham could have rail service operating, the energy shortage could either be a boon or a barrier to the community's growth.

The methods recommended for implementing the local growth policies of Plymouth and Wareham are only a few of the possible plans these towns could use to achieve their respective goals. Continued planning is the key ingredient to successfully controlling future expansion. 
VI. CONCLUSION 
The management of growth is increasingly becoming a top priority for towns throughout the nation. The state of Massachusetts has joined the country's leaders in encouraging local communities to evaluate their current status in terms of demographic, economic, and social/cultural development. Through this process, the towns and cities of the Commonwealth adopted local growth policies to help them promote or discourage future growth, and to enable them to manage that growth which does occur.

In the implementation of these policies, problems can arise. In some instances, adjacent communities may have opposing policies toward future development. The towns of Plymouth and Wareham provide a good case study for the identification of these potential problems.

This paper examines the historic development and current demographic, housing, economic base, and political configurations of the towns of Plymouth and Wareham. An analysis of the local growth policies identifies the goal and key objectives of each town, and highlights areas of potential conflict in achieving them. In conjunction with this analysis, alternative methods of implementing these policies are proposed which may help the towns plan for future growth. It is hoped that these two communities, and others in similar situations, will continue to cooperate with each other (possibly through regional planning organizations) in an effort to promote manageable growth in the future. 
MAPS 


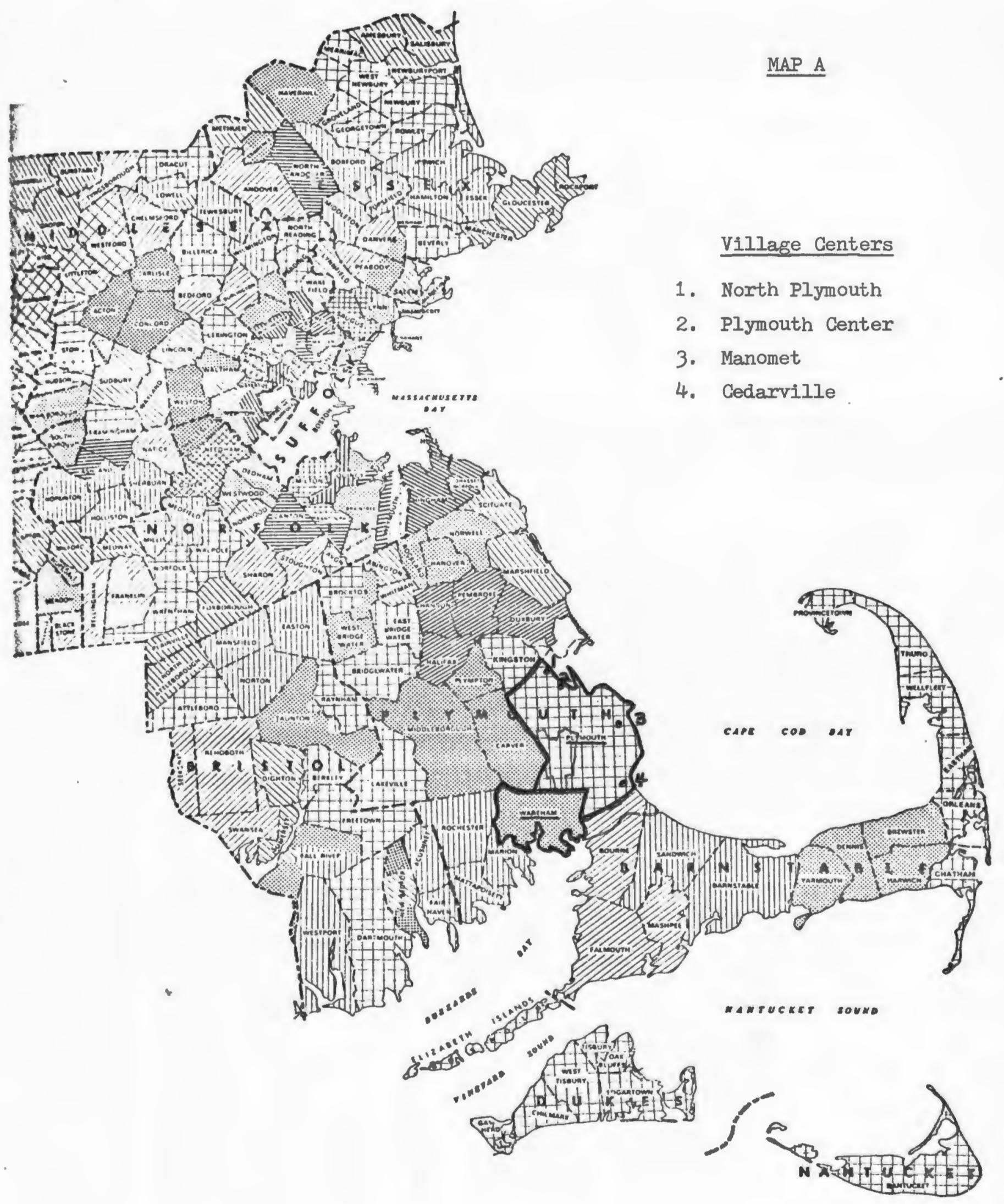




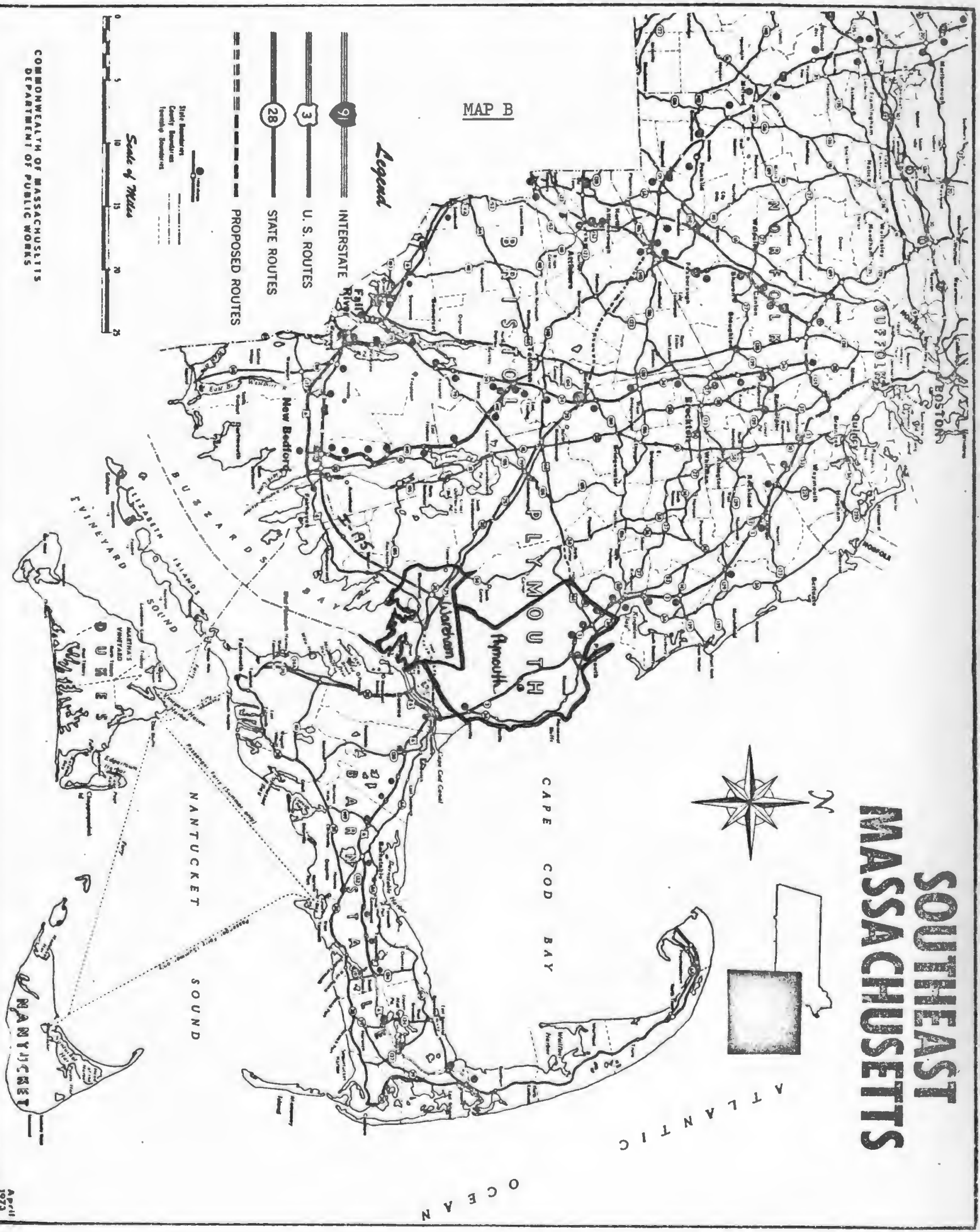


APPENDIX 
In the course of my research for this project, I was plagued by a lack of usuable information and an unwillingness on the part of some town employees to part with what was available. During my initial inquiries, it became apparent that both of the towns of Plymouth and Wareham were reluctant to deal with, or impart information to, a student even one completing a Masters in Community Planning. All attempts at seeking information or scheduling appointments over the telephone proved to be fruitless. I was both surprized and frustrated by their attitudes; the information I was seeking at that time was largely part of the public record.

In an effort to compile basic information about each town regarding their demographic, economic, and political characteristics, I was forced to contact the State Department of Commerce and Economic Development. This department was very helpful and provided me with monographs for each town (which had been unavailable at the town halls), and a list of publications available at the library which might supply additional information. It was fortunate that I was familiar with the two towns and had some personal knowledge of their development patterns over the last decade.

Following a number of personal visits, the Plymouth planning office appeared more receptive to my inquiries and was willing to discuss their 
growth policy in addition to providing me with copies of the policy and a summary of the town's goal statement. (Plymouth is in the process of developing its first master plan.) Wareham, on the other hand, continued to turn me away. I was told the town had no growth policy, at which point I informed them that they were required to file one with the Massachusetts Office of State Planning in a 1975 ruling. I was told to go to Boston for the information. I was also informed that Wareham had no master plan, no goal statement, no developing policy, and had not updated its growth policy since 1976. I subsequently discovered that, in fact, the town had all of these.

Each of the documents I requested from the town of Wareham are (or should be) a matter of public record. I an baffled at the town's reluctance to allow me to see them. I cannot believe that the employees of the town hall are completely ignorant of the existence of these documents, nor can I linderstand their reluctance to help anyone find information - student or not. The information I was able to collect did not suggest that the town had anything to hide. It is regrettable that students must face professional prejudices in their quest for information. It is even more regrettable that a citizen cannot learn about the past and future development of her birthplace. 


\section{FOOTNOTES}

Section I.

'William K. Reilly, "Use of Land: A Gitizens' Policy Guide to Urban Growth", in Management and Control of Growth, Vol. I., p. 86.

${ }^{2}$ Ibid., p. 87.

3assachusetts Office of State Planning, City and Town Centers: A Program for Growth, p. 1.

Section II. p. 32 .

${ }^{1}$ Massachusetts League of Cities and Towns, "Municipal Directory",

2Massachusetts Department of Commerce and Economic Development, Massachusetts Profile of Plymouth.

3 Ibid.

4 Ibid.

5 Massachusetts Department of Commerce and Economic Development, Massachusetts Profile of Wareham.

${ }^{6}$ Ibid.

7 Ibid.

${ }^{8}$ Ibid.

Section III.

${ }^{1}$ Plymouth Growth Policy Committee, Local Growth Policy Statement. 


\section{BIBLIOGRAPHY}

Agelasto, Michael A.. "No-Growth and the Poor: Equity Considerations in Controlled Growth Policies", in Management and Control of Growth. Vol. I. Ed. Randall W. Scott. Washington D.C.: Urban Iand Institute, 1975, pp. 426-438.

Alonso, William. "Urban Zero Population Growth", in Management and Control of Growth. Vol. I. Ed. Randall W. Scott. Washington D.C.: Urban Land Institute, 1975, pp. 405-414.

"Directory of Social, Health, Welfare, and Rehabilitation Services in Massachusetts", prepared by United Community Services of Metropolitan Boston. Boston, 1968.

Johnson, Willard R.. "Should the Poor Buy No-Growth?", in Management and Control of Growth. Vol. I. Ed. Randall W. Scott. Washington D.C.: Urban Iand Institute, 1975, pp. 415-425.

Massachusetts Department of Commerce and Economic Development. Massachusetts Profile of Plymouth. Boston, 1975.

Massachusetts Department of Commerce and Economic Development. Massachusetts Profile of Wareham. Boston, 1975.

Massachusetts Office of State Planning. City and Town Centers: A Program for Growth. Boston, 1977.

Miner, Dallas D.. "Citizen Involvement: Problems, Progress, and Promise", in Management and Control of Growth. Vol. IV. Eds. Frank Schnidman, Jane A. Silverman, and Rufus C. Young, Jr.. Washington D. C.: Urban Land Institute, 1978, pp. 283-285.

"Municipal Directory", prepared by Massachusetts League of Cities and Towns. Boston, 1978.

Peterson, Russell W.. "A Hierarchy of Needs - In the Limiting of Growth", in Management and Control of Growth. Vol. I. Ed. Randall W. Scott. Washington D.C.: Urban Land Institute, 1975, pp. 359-363. 
Plymouth Growth Policy Committee. Local Growth Policy Statement. Plymouth, 1976.

Reilly, William K.. "The Use of Iand: A Gitizens' Policy Guide to Urban Growth", in Management and Control of Growth. Vol. I. Ed. Randall W. Scott. Washington D. C.: Urban Land Institute, 1975, pp. 85-99.

Social Developers of the South Shore. Greater Plymouth Directory of Human Services. Plymouth, 1976.

Social Developers of the South Shore. Where Help Is: A Guide to Community Services of the Greater Plymouth Area. Plymouth, 1977.

Thompson, Wilbur R.. "Problems that Sprout in the Shadow of No-Growth", in Management and Control of Growth. Vol. I. Ed. Randall W. Scott. Washington D.C.: Urban Land Institute, 1975, pp. 398-404.

Wareham Growth Policy Committee. Local Growth Policy Statement. Wareham, 1976.

Zeckhauser, Richard. "The Risks of Growth", in Management and Control of Growth. Vol. I. Ed. Randall W. Scott. Wahsington D.C.: Urban Iand Institute, 1975, pp. 339-347. 


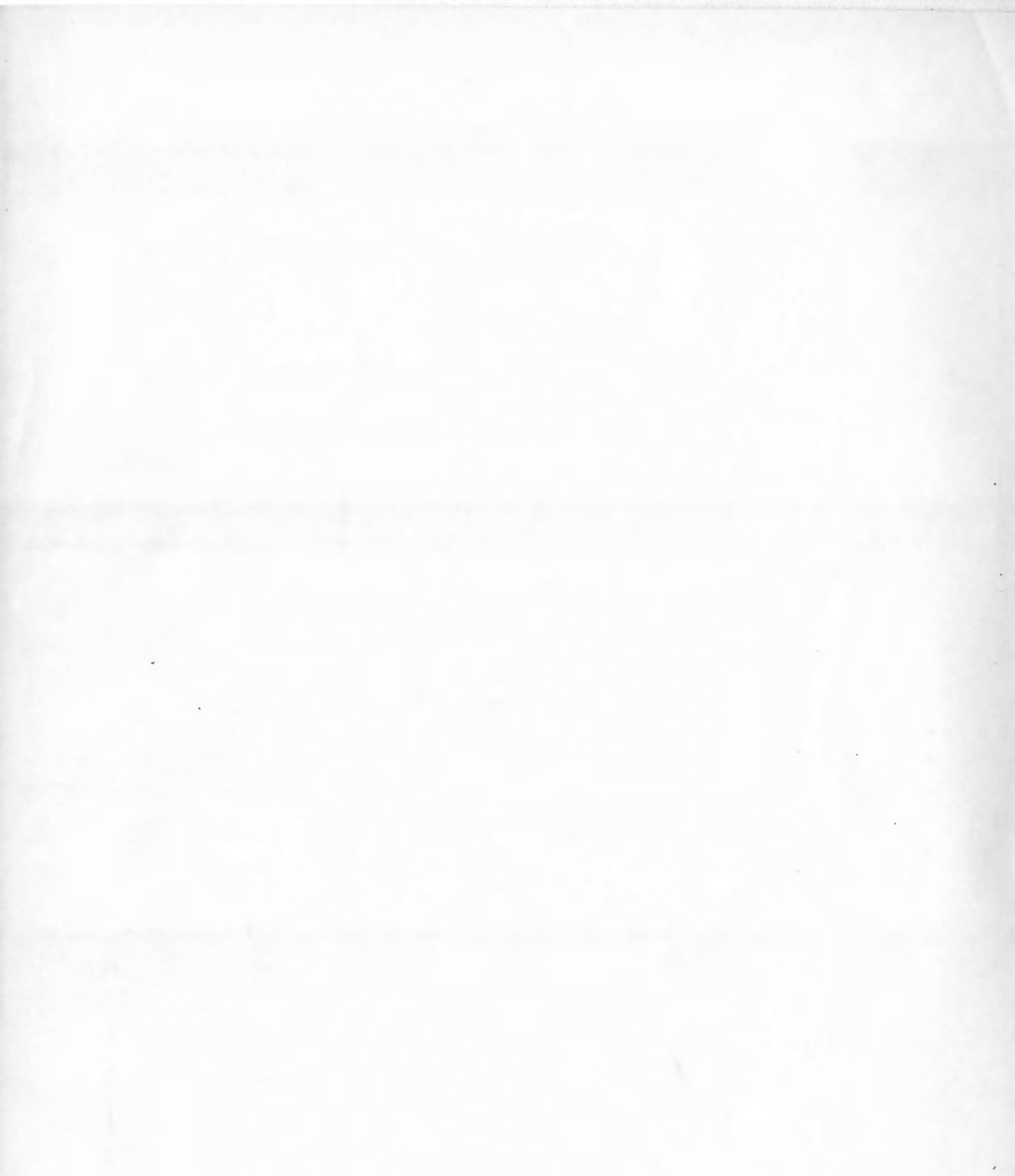

